\title{
Role of Mass Media on Mankind: Time to Rethink
}

\author{
Prasuna Jelly ${ }^{1}$, Suman Choudhary ${ }^{2}$, Rakesh Sharma ${ }^{3}$, Prakash Mahala ${ }^{4}$, Pradeep Aggarwal ${ }^{5}$
}

\begin{abstract}
In the era of 21st century, mass media is important part of everyone's life which includes e-mails, online marketing, education sites, etc. Media and computer facilitated new skills that enable the formation and discussion of ideas, problems, data, and views and in another way of presence via network and communities. This review covers all features of mass media with its positive as well as negative aspects. With the emphasis of media on areas such as education, community, children, adolescent, obesity, sexuality, and business, etc., therefore, this research review describes how mass media will comprehensively affect all aspects. Since 2000, mass media has blossomed to prospect and is still growing limitlessly sideways with media sharing, and several other entries that offered real-time updates were announced by the example of Twitter, Facebook, etc. It has become the vital part of everyone's life.

Search strategy: Articles were extracted using MESH keywords, such as children, adolescents, human, electronic mail, mass media, marketing, and health education, etc., from Embase, PubMed, and Google Scholar search engine. For additional information, we also used literature to obtain information on mass media impact in several fields. Mass media use has grown up exponentially over the past era, and this growth is expected to continue. It has a drastic impact on lives of all age-groups. Mass media is an essential or significant force in this modern civilization which has an impact on several aspects of human life. Overall, mass media has both positive effects and negative effects, but overuse of mass media may lead to a tendency of antisocial behavior.
\end{abstract}

Keywords: Adolescent, Child, Electronic media, Health education, Humans, Marketing, Obesity, Social media.

Pondicherry Journal of Nursing (2021): 10.5005/jp-journals-10084-12167

\section{INTRODUCTION}

Presently, mass media plays a main role in the day-to-day life, and media has become an essential part of life. Mass media, such as television, radio, movies, computer, and cell-phone, etc., are expected to play crucial roles in our children's routine lives.

The media has reported profound effects both positive and negative on children's behavioral and cognitive development as well as social life. ${ }^{1}$ In early childhood, there is intensifying use of media, which significantly affects kids and the young generation; moreover, it becomes an essential element of education. Within a short time, it is challenging to envisage the creation without such worldwide media and the Internet that we use routine life.

The impact of media on the development of psychology of kids is profound. Media is not the only source of entertainment or information but also a resource of the statement. By using media, we get to connect with near and dear ones who are living quite far from us. "MEDIA YOUTHFUL" describes the impact of mass media on the young generation, influencing relationships, behavioral change, knowledge gain, skills update, and emotional changes. Mass media is a lifetime appendage of children, as they use computers, watch television, and use mobile phones and Internet connection. Frequent use of media does not leave a way to escape from the impact on social life. Self-directed applications and websites facilitate the users to fulfill their purpose without any guidance, and facilitation may also move toward constructive or destructive directions. Special attention to the children as well as adults who do not have the wisdom to think what is right and wrong leads them to put in challenges and trouble situations. ${ }^{2}$

\section{Popular Sites of Media}

Around the world, media is a platform to describe people's opinions and issues. Everyone is getting up in the morning with cell phones and till they go to bed in the night are busy

\footnotetext{
1,3 College of Nursing, All India Institute of Medical Sciences, Rishikesh, Uttarakhand, India
}

${ }^{2}$ Department of Microbiology, All India Institute of Medical Sciences, Rishikesh, Uttarakhand, India

${ }^{4}$ Department of Emergency, All India Institute of Medical Sciences, Rishikesh, Uttarakhand, India

${ }^{5}$ Department of Community and Family Medicine, All India Institute of Medical Sciences, Rishikesh, Uttarakhand, India

Corresponding Author: Rakesh Sharma, College of Nursing, All India Institute of Medical Sciences, Rishikesh, Uttarakhand, India, Phone: +91-9639553333, e-mail: rakesh5533333@gmail.com

How to cite this article: Jelly $P$, Choudhary S, Sharma R, Mahala $P$, Aggarwal P. Role of Mass Media on Mankind: Time to Rethink. Pon J Nurs 2021;14(2):37-41.

Source of support: Nil

Conflict of interest: None

communicating through social networking sites, such as Facebook, Instagram, YouTube, Snapchat, Twitter, etc., which is why media is a key feature in human life. The role of media is to convert the behavior of the young generation, their blood relation, and friends, but it also depends on how they practice social media technology ${ }^{3}$ (Fig. 1).

\section{Impact of Media on Education}

The media is a future of negotiation, which includes tools that are based on net and platform. Media improves and enhances information or data experience. The mass media platform is about content sharing, input on the community-based contact and reconciliation. In India, till 2014, on YouTube, the national program on an e-learning engineering course and technology-enhanced learning were seen by 110 million. In 2013, social media was used as 


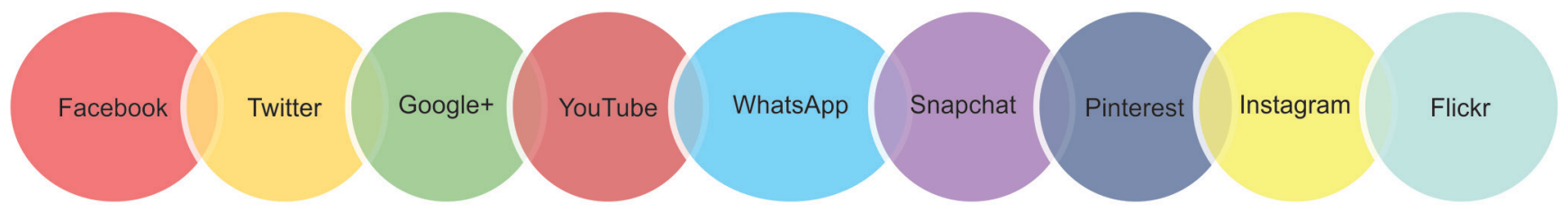

Fig. 1: Popular sites of social media

a teaching tool by $41.1 \%$ of American professors. At the same time, a variety of free web applications and software tools are used by the faculty to improve commination, new learning, and to prepare for higher education by social media. ${ }^{4}$

Today, social media has turned into popular slices of life of the young generation. Mostly, people join media with short of inhibiting to consider what are the effects on their own life, whether it will be negative or positive. Some of the positive impact of social media on education are that Google has helped out 20 billion students in the educational tool; it permits the kids to discuss and learn fresh stuff, to do group projects, or for help on home and school work assignments, etc. The social media is helpful for the teachers, and they can post on social media about school events, activities of the class, and homework. It will be very beneficial to students. ${ }^{5}$ Media also helps in capability to know new belongings. This helps to refresh their information particularly. ${ }^{3}$

\section{Addiction}

It a physical or and psychological compulsion, in which individual is not able to stop to do act or eating chemical substance/drug, although he/she know the harmful effects. Addiction of media, such as regularly checking Linkedln, Twitter, Facebook, and other updates of media, is the primary bad impact of social media on children as well as adults. The addiction negatively impacts adolescents valuable activities, i.e., study concentration, taking active participation in sports, refusing realities, and communication of real life. ${ }^{6}$

\section{Privacy}

In multimedia, privacy is a big issue, such as uploading personal information on online social sites that are accessed by everyone. Several, inaccurate, and unauthentic information are available online which are manipulating and judgmental and may clue the students to the erroneous side. ${ }^{7}$ Due to this readily available information on social media, the students lose their capability to engage themselves for one-to-one communication and less concentration on classes. Several bloggers and writers post erroneous information on social media platform which leads the education system to fiasco. ${ }^{8}$

Studies have been confirmed that children's behavior is affected by advertising on social media. Children up to the age-group 4 or 5 years are not making a difference between reality and social media content. ${ }^{9,10}$ According to Article 17 of the Convention on the Rights of the Child, all children must be protected from any kind of content that could harm children physically and mentally. The fact is that, there was no significant improvement in the last few years, which is confirmed by Children's Ombudsman Report for the year 2013.11 It is also addressed that reporting of unsuccessful efforts in view of protecting children in the relation of inadequate regulation in such area. It is also evident that there are many legal hurdles to maximize the possibilities to protect children from various consequences of advertisements. ${ }^{12}$

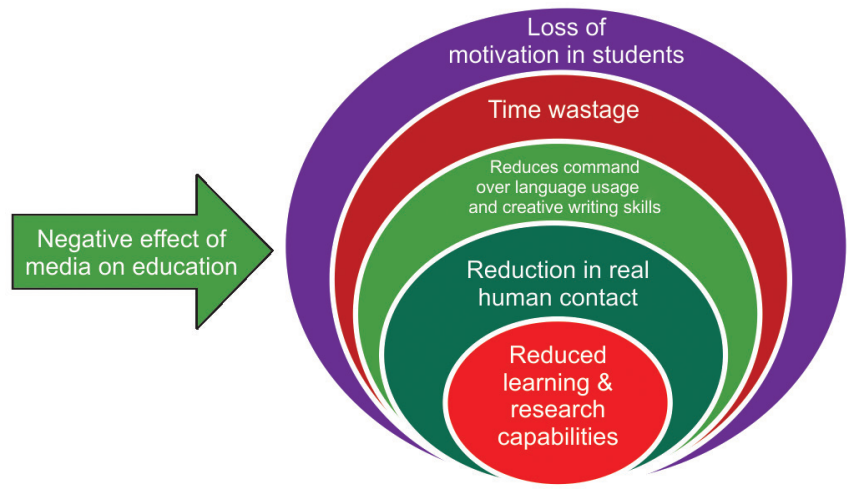

Fig. 2: Negative effect of media on education

The use of social media and networking tools in education to support teachers and a balanced education system has been explored. A study has shown that almost $91 \%$ of teachers used various kinds of social media tools such as e-mail, slide share, WhatsApp, and Facebook, and use of YouTube was the highest. In all, $63 \%$ teachers admitted that they have basic skills required to use this kind of social media tools in education. In case of usability of these tools, $50 \%$ of them were using on a daily basis, and $17 \%$ and $12 \%$ used it on weekly basis and monthly basis, respectively. It is indicated that in educational system, social media has given deeper benefits ${ }^{13}$ (Fig. 2).

\section{Media and Teenagers}

Media is a huge part of many teenagers' lives. A survey of nearly 750 in 2018 between the age of 13 and 17 years found that $45 \%$ are online regularly, and $97.1 \%$ use platform of social media. In the United States, 12- to 15-year-olds who used up 3 hours per day in 2019 are found to be at higher risk of mental health, whereas more than 12,000 those in England between the age of 13 and 16 years were found using media. ${ }^{14}$ Nowadays, broadcasting has a massive impact; Be it video games, social networking sites and computers, and television-this broadly holds all sides of a kid's life.

According to a recent surevey, more than half of adolescents and $22 \%$ teenagers are logging their favorite site of media per day or more than 10 times a day. Most (75\%) of teenagers have their own phone now, with $24 \%$ using it for messaging, 54\% for texting, and $25 \%$ for mass media. Most parents used technology unlimited and feel relaxed and skilled with program and online settings that their adolescents and children are using. ${ }^{15,16}$ Impact of media on teenagers is depicted in Flowchart 1.

\section{Impact of Media on Society}

Media and society are very close to each other. Mass media acts as an umbrella that develops very interesting features to make life easier such as tagging friends, video and photos upload, sharing 
Flowchart 1: Impact of social media on kids and teens

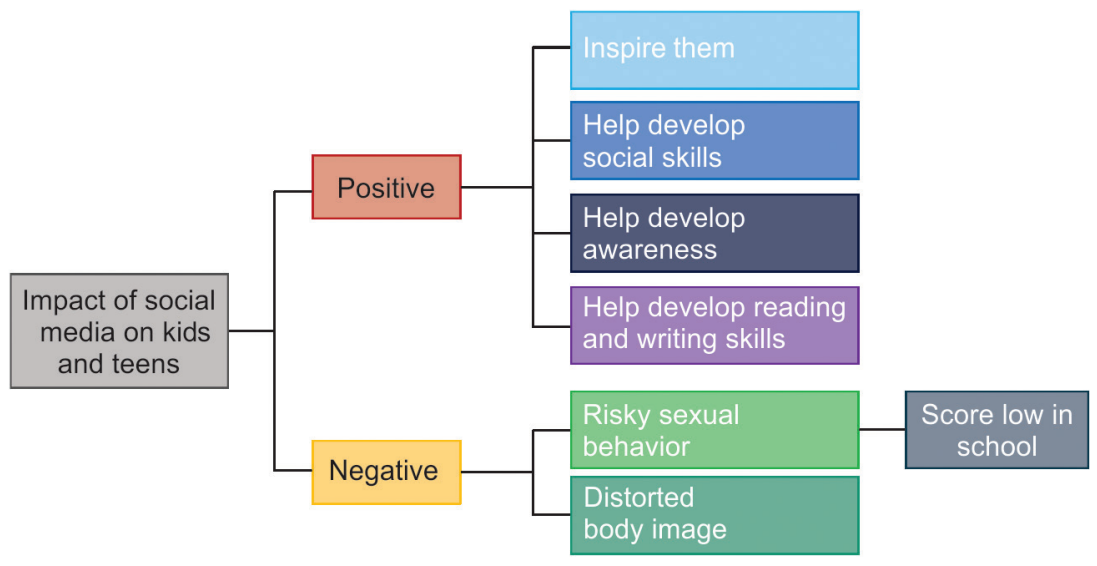

of location, video calling, chatting, etc. A study revealed that $70 \%$ use media every day for getting up-to-date information. ${ }^{17}$ Media works as a vehicle for news, conveying massage, and is helpful in entertainment and education. ${ }^{18}$ In 2015, a survey reported that by Pew Internet research that media users among adult Americans those use single networking site has raised from 10.01 to $76.01 \%$ since $2005 .^{19}$

Social media provides opportunity for generation to reconnect with their colleagues, friends, and relatives. It is also helpful to make new contents, friends, audios, pictures, and videos between them. Social media also fluctuates society lifestyle such as culture, norms, and work. ${ }^{8}$

Through social media, people interact more easily with everyone. It gives the opportunity to upload present activities around in the global. In contrast, fake messages are spread easily by mass media, leading to disequilibrium in community harmony. Confidentiality and private life of people are unsafe. Robbery is second issue that can give financial losses to anyone by hacking their personal accounts. The addictive broadcasting part is wicked and may distract private lives as well. Youths are more obsessed with media and loosing connection with social life. Social media may simply decay somebody's status only by generating a fake division and dispersal through the social media. ${ }^{20}$

\section{Impact of Social Media on Business}

In the present era, many business executives, mass media concept has reached the top agenda. Many information technology (IT) companies are trying to find out ways to make profitable apps use like YouTube, Facebook, Instagram, etc. The social media phenomenon significantly influences sales, reputation, and survival. ${ }^{21}$ The importance of media in business is increasing. With more people joining social media sites and using them continuously/capably, the social media business is bound to become larger in the coming years; it is growing like never earlier. ${ }^{22}$

Nowadays, people take the help of media to comprehend their spectators by their dislikes and likes; it can be an economic saver and a grovel business with its clients. Media also permits a business to answer to its customers and make any alteration quickly. ${ }^{23}$ Social media in business field is not totally risk free, as many of the devotees and followers are free to post their views on a precise organization, and the negative comment can clue the organization to a let-down. ${ }^{8}$

\section{Media and Substances Use}

Alcohol, tobacco, and cigarette industries have huge integration with media platforms with strategies in marketing that are fully available to teenagers. A study at Columbia University in 2011 reported that those who used social media sites were more frequent to use alcohol and tobacco in comparison to those do not use media which is reported by National Center on Addiction and Substances Use. ${ }^{24}$ Many young adults and adolescents are exposed to use of substances, which are seen on media, i.e., social sites of network and brand websites. Use of these substances create negative effects on cognitive capacities in experience of real life. ${ }^{25}$ National survey on drug use and health in 2014 reported that 1 in 10 Americans waged 12 or older had disorders of substances use. ${ }^{26,27}$ In the recent years, mass media sites like Facebook, Myspace, and YouTube have grown rapidly to share information to larger population.

\section{Impact of Media on Maternity Care}

Childbirth is an anxiety-producing situation for many women and represents the most painful event in women's lifetime. ${ }^{28}$ Some pregnancy required extra monitoring because it is considered high-risk pregnancy. ${ }^{29}$ Pregnant women receive a great value on the data and provision from sharing using online apps and query. Some of the apps deliver information on how to monitor infants' sleeping, growth, development, and feeding. Health apps and social media are increasingly used in pregnancy care. Social media and apps have the latent to be broadly used in improving maternal well-being during the prenatal and postnatal stages. ${ }^{29}$

\section{Media Impact and Risk of Early Sexual Initiation and Sexual Promiscuity}

Television showed sexual material more than $50.1 \%$, prime time shows with sexual content $66.0 \%$, and $9 \%$ of the shows to any reference to responsibility, risk or safer sex, and contraception. Dangerous sexual behavior include early unsafe sex, and sexual debut with multiple sexual partners is paid more attention globally for its remote negative influence many health problems such as HIV and sexually transmitted infections (STIs) and many diseases such as use of substance and teenage pregnancy. ${ }^{30}$ Risky sexual behavior in adults is influenced by more essential domains of life such as peers, parents, relatives, and individual factors, for example, factor regarding parents or family, i.e., low control by parents or family, low impulsive control, negative emotions, and early maltreatment. ${ }^{31}$ 
It is also stated that a large number of adolescences are identified having unprotected sex which has maximum influence on youth. ${ }^{32}$ Sexual activities at early stage of life among youth is due to exposure to sexually explicit content in mass media. In media, there is increased and explicit portrayal of sexual material. ${ }^{33,34}$

A study showed that media had negative influence on the sexual wellness of many adolescent users as adolescents could easily fall to online effect of disinhibiting. It indicates that private information and personal details are more released into domains of public than they would be face-to-face interaction due to dissociative anonymity that social networking sites provide. So, adolescents are riskier group for contracting sexually transmitted infection, and approximately 3 million are infected yearly. ${ }^{35}$ Media also provides information regarding contraception and protective medication.

\section{Media and Obesity}

According to the World Health Organization in 2016, around 170 million children below the age of 18 years are suffering from obesity. ${ }^{36,37}$ In Western population, media is a reason for increase in obesity. In 1985, a first study suggested a relation between media and obesity and summarized the increased prevalence of obesity of $2.01 \%$ in age of 12-17 years for extra hour of television watched. Media mostly motivates a sedentary lifestyle, and advertisement mainly encourages unhealthy foods. ${ }^{38}$

According to survey of CDC of US, more than half residents watched TV twice per week responded that TV presents accurate information. So it is also good news that media have to promote health and discourage prejudice. ${ }^{39}$ The main reason of consumption of unhealthy food is advertisement. Most research state that during advertising children and youth use additional food such as snacks (mainly salty and sweet snacks) and frequently use of low-nutrient drinks, i.e., fizzy drinks, coffee, tea, and alcohol. ${ }^{37}$ It is also proved that media may increase awareness related to health issues, but it is less evidenced that mass media may stimulate change in behavior ${ }^{38}$ because mass media is mainly responsible for creating a good platform for a variety of recipes that influence health.

\section{Conclusion}

Social media has influenced human kind in the various fields in both positive and negative directions. In the education field, current research shows students obtain new skills and get the education quality but at the same time may get distracted and use social media too much. The social networking websites have developed important requisite today; therefore, it could not be encouraged at all. The media pleased, frequently overstated, and grow into something smart or smooth reasonable to actual effects that may progress "exact media attentive belongs to moral and cognitive belief and lastly to the inactive consumerism outlook of sightless mock.

\section{References}

1. Ray M, Jat KR. Effect of electronic media on children. Indian Pediatr 2010;47(7):561-568. DOI: 10.1007/s13312-010-0128-9.

2. Matyjas B. Mass media and children. Globality in everyday life. Procedia - Social and Behavioral Sciences 2015;174:2898-2904. DOI: 10.1016/j.sbspro.2015.01.1026.
3. Akram W, Kumar R. A study on positive and negative effects of social media on society. Int J Comp Sci Engineer 2017;5(10):351-354. DOI: 10.26438/ijcse/v5i10.351354.

4. Raut Prafulla Patil V. International journal on recent and innovation trends in computing and communication use of social media in education: positive and negative impact on the students. Int J Rec Innovat Trends Comput Communicat 2016;4(1):281-285.

5. Siddiqui S, Singh T. Social media its impact with positive and negative aspects. Int J Comp Applicat Technol Res 2016;5(2):71-75. DOI: 10.7753/IJCATR0502.1006.

6. Ayeni PT. Social media addiction: symptoms and way forward. The American Journal of Interdisciplinary Innovations and Research 2019;1(04):XIX-XLII.

7. Cain J, Fink JL. Legal and ethical issues regarding social media and pharmacy education. Am J Pharmaceut Educat [Internet] 2010;74(10):184. DOI: 10.5688/aj7410184Available from:/pmc/articles/ PMC3058471/?report=abstract.

8. Rajalakshmi V. A study on impact of social media on business. Emp Int J Finan Manage Res 2019;5(4):32-37. DOI: 10.35337/EIJFMR. 2019.5406.

9. Impact of media use on children and youth. Paediatrics \& Child Health [Internet] 2003;8(5):306. Available from: https://www.ncbi.nlm.nih. gov/pmc/articles/PMC2792691/.

10. Appel G, Grewal L, Hadi R, Stephen AT. The future of social media in marketing. J Acad Market Sci [Internet] 2020;48(1):79-95. DOI: 10.1007/ s11747-019-00695-1.

11. Lansdown G. Every child's right to be heard: a resource guide on the UN committee on the rights of the child general comment no. 12 [internet]. London: Save the Children/United Nations Children's Fund; 2011. Available from: https://www.unicef.org/files/Every_ Childs_Right_to_be_Heard.pdf.

12. Messages A, Media IN. $7 / 16 / 2020$ advertising messages in media and education for media |Jadranka Pavic|Research Project. 2020; pp. 1-2.

13. Kaur J, Gupta D. Impact of emerging technologies in social media on education-A study. Int J Res Adv Technol 2018;6(3):200-206.

14. Clinic M. Tween and teen health. 2013. 1-2. Available from: https:// www.mayoclinic.org/healthy-lifestyle/tween-and-teen-health/ basics/tween-and-teen-health/hlv-20049436.

15. O'keeffe GS, Clarke-Pearson K. The impact of social media on children, adolescents, and families abstract. Pediatrics 2011;127(4):800-804. DOI: 10.1542/peds.2011-0054.

16. Undiyaundeye F. Impact of social media on children, adolescents and families. Global J Interdisciplin Soc Sci 2014;3(2):1-4.

17. Pandey GSN. Role and impact of media on society: a sociologica approach with respect to demonetisation. Int J Res Humanit, Arts Literat 2017;5(10):127-136.

18. Mehraj HK, Bhat AN, Mehraj HR. Impacts of media on society: a sociological perspective. Int J Humanit Soc Sci Invent ISSN (Online) 2014;3(6):56-64.

19. Harchekar JS. Impact of social media on society. Int J Engineer Res 2017;6(07):2015-2017.

20. Lad $H$. The positive and negative impact of social media on "Education, teenagers, business and society" Harshit lad. Int J Innovat Res Sci 2017;6(10):19652-19657.

21. Kumar M, Singh S, Farwaha HS. Optimization and prediction of sintering process parameters for magnetic abrasives preparation using response surface methodology. Int J Data Network Sci 2019;3(2):103-108. DOI: 10.5267/j.ijdns.2018.12.005.

22. Value $B$. The importance of social media in business $3 x$ your business value. Life Marketing 2019; 1-17.

23. Al Bakri A, Read M. Social media: adoption and legal issues impact on business innovation international journal of business innovation and article/chapter tools search keep in touch. Int J Busin Innovat Res 2020;9(4):1-2.

24. Costello CR, Ramo DE. Social media and substance use: What should we be recommending to teens and their parents? J Adoles Health 2017;60(6):629-630. DOI: 10.1016/j.jadohealth.2017.03.017. 
25. Jackson KM, Janssen T, Gabrielli J. Media/marketing influences on adolescent and young adult substance abuse. Curr Addict Rep 2018;5(2):146-157. DOI: 10.1007/s40429-018-0199-6.

26. Ding T, Bickel WK, Pan S. Multi-view unsupervised user feature embedding for social media-based substance use prediction. EMNLP 2017 - Conference on Empirical Methods in Natural Language Processing, Proceedings. 2017; pp. 2275-2284.

27. Ding T, Bickel WK, Pan S. Social Media-based Substance Use Prediction. 2017.

28. Choudhary S, Prakash K, Mahalingam G, Mahala P. Effectiveness of labor support measures on the pain perception of mothers in labor. Int J Med Sci Pub Health 2018;7(5):1. DOI: 10.5455/ ijmsph.2018.0204519022018.

29. Chan KL, Chen M. Effects of social media and mobile health apps on pregnancy care: meta-analysis. JMIR Mhealth Uhealth 2019;7(1):1-11. DOI: 10.2196/11836.

30. Brady M. Preventing sexually transmitted infections and unintended pregnancy, and safeguarding fertility: triple protection needs of young women. Reproduct Health Matt [Internet] 2003;11(22):134-141. Available from: https://www.tandfonline.com/doi/full/10.1016/ S0968-8080\%2803\%2902289-4.

31. Lin WH, Liu CH, Yi CC. Exposure to sexually explicit media in early adolescence is related to risky sexual behavior in emerging adulthood. PLoS ONE 2020;15(4):1-29. DOI: 10.1371/journal. pone. 0230242 .
32. Collins RL, Martino SC, Shaw R. Influence of new media on adolescent sexual health: evidence and opportunities. RAND Health [Internet] 2011(April):1-72. Available from: papers2://publication/ uuid/3C158F41-078C-4B43-82B7-91F5F4D4D48F.

33. Agarwal V, Dhanasekaran S. Harmful effects of media on children and adolescents. J Indian Associat Child Adoles Ment Health 2012;8(2):38-45.

34. Holmgren HG, Padilla-Walker LM, Stockdale LA, Coyne SM. Parental media monitoring, prosocial violent media exposure, and adolescents' prosocial and aggressive behaviors. Aggress Behav 2019;45(6):671-681. DOI: 10.1002/ab.21861.

35. Cookingham LM, Ryan GL. The impact of social media on the sexual and social wellness of adolescents. J Pediatr Adolesc Gynecol 2015;28(1):2-5. DOI: 10.1016/j.jpag.2014.03.001.

36. Khajeheian D, Colabi AM, Shah NBAK, Radzi CWJBWM, Jenatabadi HS. Effect of social media on child obesity: application of structural equation modeling with the Taguchi method. Int J Environ Res Public Health 2018;15(7):1-28. DOI: 10.3390/ijerph15071343.

37. Pal R, Singh GM, Sharma R. Eating habits and selected psycho-physical parameters among adolescent girls in a selected educational institute of Uttarakhand. Int J Psychiat Nurs 2017;3(1):19-25. DOI: 10.5958/2395180X.2017.00004.4.

38. Boyce T.The media and obesity. Obesity Rev 2007;8(Suppl. 1):201-205. DOI: 10.1111/j.1467-789X.2007.00342.x.

39. Whyte J. Media portrayal of people who are obese. Virtual Mentor 2010;12(4):321-324. 